\title{
Grape Seed Extract and its Effects on Diabetes and its Complications
}

\author{
Vidhushini Sekar ${ }^{2}$ and Hannah R Vasanthi ${ }^{1 *}$ \\ Department of Biotechnology, University of Pondicherry, India
}

Submission: Febrauary 13, 2017; Published: May 04, 2017

*Corresponding author: A Hannah Rachel Vasanthi, Natural Products Research, Laboratory, Department of Biotechnology, Pondicherry University, India, Tel: +91-9443135842; Email: hrvasanthi@gmail.com

\begin{abstract}
The steady exponential increase of the number of diabetics world over, demands the challenge of undertaking novel therapeutic measures to counteract the fatal disease: Diabetes mellitus. Based on the current global statistics, it is safe to assume that the human population is in the midst of a Diabetes epidemic. Despite novel therapeutic and pharmacological approach to counteract this epidemic, diabetes still poses a threat as its complications leads to major associated disorders mounting to huge economic burdens as well. Phytochemicals and natural therapeutic approaches have been increasingly proven to provide a head on approach to deal with disease and its related disorders. The phytoconstituents of grapes have proven to be a treasure chest of relevant potential pharmacological lead molecules to manage and cure metabolic disorders. This review deals with various comprehensive approaches of bioactive molecules present in grape seed extract and their effective nature in treating chronic hyperglycemia.
\end{abstract}

Keywords: Grape Seed Extract; Diabetes mellitus; Diabetes micro vascular complications

Abbreviations: GSE: Grape Seed Extract; STZ: Streptozotocin; ROS: Reactive Oxygen Species

\section{Introduction}

It is estimated by 2030 there will be 205 million more people with diabetes in addition to the 387 million currently on board. According to this estimate at present, for every twelve individuals in the world one among them is affected by diabetes [1-3]. India however has an alarming statistical report of 62.1 million diabetics with a 100 million of total population and by 2030 this number of diabetics is predicted to escalate to nearly 79.4 million [4,5]. Diabetes is commonly referred as a 'metabolic disorder', 'a life-style disease', now diabetes can also be referred 'the most expensive disease' as well, partly because it is considered an epidemic and currently around US $\$ 376$ million is been sent on diabetic care and research, which will be projected to exceed US $\$ 490$ million by 2030 [6]. Parallel to this expenditure, India spends around 180,000 million Rupees on the same cause annually [7]. Despite the amount of resources spend to curb this insidious disease in our hand, the cure or the solutions always seem to be elusive.

To sustain the plethora of molecular and biochemical activities, the cells are in a constant need for energy or glucose. Most of the glucose supplemented to plasma is through dietary sources or non-dietary sources through glycogenolysis, formation of glucose via other carbon compounds in the system like pyruvate, lactate, amino acids etc [8]. The anatagonistic role of glucagon and insulin hormones plays a vital role in the homeostasis of plasma glucose level. However faulty insulin secretion and or insulin resistance along with genetic and environmental factors most often result in hyperglycemic condition of the cell. At this stage, diabetes is the summation of chronic hyperglycemic condition in the cell $[9,10]$.

Prolonged diabetic condition in the system also leads to further deleterious effect known as diabetes related complications which could be classified as macro vascular complications which include obesity, coronary heart disease etc and micro vascular complications which includes diabetic nephropathy, retinopathy and neuropathy. Less to none physical activity, stressed lifestyle, overconsumption of high calorie diet along with genetic and medical factors for a prolonged time without proper treatment or adequate 


\section{Current Research in Diabetes \& Obesity Journal}

lifestyle modifications may very often lead to morbidity and mortality $[11,12]$. But the actual treatment of diabetes is aimed at maintaining normal, clinically significant glucose values, to create a comparable normal quality of and to prevent the progression of diabetes related vascular complications with the intervention of drugs. Chronic hyperglycemia may be a major reason for diabetic complications but it is not the only reason, oxidative stress resulted through glucose toxicity in cell acts as a major contributor for diabetic complications [13]. Hyperglycemic conditions in the cell persuades the ROS production through various mechanisms like advanced glycation end products, sorbitol accumulation, cytokines activation etc. Hence a more sensible way to curb diabetes is to not only treat the presenting condition but to act on various molecular and biochemical levels [14]. This review analyses the various compounds present in the grape seed extract, bioactivity and its efficacy against the biochemical and molecular conditions of diabetes and its related complications.

\section{The seed for diabetes - Grapes and Grape seed extract}

Among many theories and paradoxes about Diabetes mellitus and its complications, the most interesting one is 'the French paradox'. According to this paradox, the French people consume far more mono saturated fatty acids than the Americans; however when it comes to metabolic disorders like diabetes, obesity or cardiovascular diseases, the Americans are more prone than the French. The possible explanation in conjecture to this observation is that the French people consume more wine than the Americans. Many scientific studies have said the polyphenols and flavanoids present in red wine might be the contributing factor for this conundrum [15].

The wine contains certain phenolic compounds like proanthocyanidins, epicatechin, dimeric procanidin, gallic acid which are also present in the grape seed extract [16]. The development of health supplement from phytochemicals proves to be an exciting research opportunity for many diseases especially pertaining to the metabolic disorders. Grape seed extract (GSE) is one such excellent health supplement from natural sources (mainly from the grape species European grapes-Vitis vinifera, North American grapes - Vitis labrusca and Vitis rotundifolia, and Hybrids of certain French varieties [17].

Grape seed extract is the by-product of wine and juice processing industry. A majority of oligomeric proanthocyanidins are present in commercialized, standard grape seed extract with an inculsion of around 5\%-8\% of monomeric flavanols. GSE has a rich source of catechin, epicatechin, epicatechin-3-0-Gallate along with the most potent and readily available proanthocyanidins also with these monomeric phenolic compounds, grape seed extract has a rich source of dimeric, trimeric and tetrameric procyanidin. The red color and astringency taste of the GSE can be attributed to polyphenol rich compounds especially proanthocyanidins which may affect the color and sensory characteristics of the extract $[16,18,19]$.

\section{Grape Seed Extract takes on Diabetes}

Diabetes is an unhealthy culmination of different factors which affect and alters metabolism at various levels. The basic therapeutic approach towards the treatment of diabetes is by reducing the postparandial hyperglycemia by attenuating the absorption of glucose. In a normal, metabolic condition, this is achieved by the enzymes alpha-glucosidase, alpha-amylase and pancreatic lipase $[20,21]$. The ethyl acetate fraction of Muscadine grapes (Vitis roundifolia) has anti-glucosidase and pancreatic lipase activity which could be attributed to the phenolics such as quercetin and ellagic acid, present in the seeds [21] also the aqueous extract of grape seeds are potent alpha glucosidase and alpha amylase inhibitors [22]. The oligomers of grape seed procyanidin extract phosphorylates the insulin receptor and thus activates to increased cellular glucose uptake in 3T3L1 cells [23]. Further it was confirmed that procyanidins from the grapes increased the cellular glucose uptake in insulin sensitive L6E9 and 3T3L1 cell lines by insulin-mimetic property [24].

The antioxidant activity of any compound refers to the delay or inhibition of step of the oxidative chain reactions or forming stable radicals [25] the effect of platelet release from reactive oxygen species incubated with the extracts from grape skins or seeds were examined and the results led to an immediate attenuation of release of the inflammatory mediator, soluble CD40 ligand which leads to the conclusion of the extract's anti-oxidant property [26]. In the diabetic rat model, oral administration of GSE reduced the levels of lipid peroxides and carbonylated proteins and improved the antioxidant activity, suggesting that the grape seed extract enhanced the antioxidant defense against reactive oxygen species produced under hyperglycaemic conditions [27].

It is not surprising that the benefits of GSE, are extended in the in vivo studies as well, this may be attributed to the fact that grape seed extract have less toxicity for regular consumption [28]. In a study of high-fructose diet induced insulin resistance and oxidative stress in rats, grape seed extract administered rats showed significant improvement in oral glucose tolerance and reduction of plasma glucose levels with insulin concentrations [29]. GSE also exhibits pronounced hypoglycemic properties in STZ induced diabetic rats [24]. When the red grape pomace extract was administered to STZ induced C57BLKS/6NCr mice, results show that there was a $35 \%$ decrease in post-parandial hyperglycemia [30].

A plausible reason behind the diabetes related vascular complications is, Advanced Glycation End products (AGE) 


\section{Current Research in Diabetes \& Obesity Journal}

or Protein Glycation products (PG). The Amadori product formed due to the reaction of free amino groups with carbonyl group of reducing sugar, forms a reactive carbonyl species such as 3-deoxyglucosone. These processes have implications in the structural and functional extracellular proteins in the vascular region, leading to vascular complications [31]. Under experimental conditions, Muscadine grape skin and seed extract have proven to inhibit the PG [32] which leaves us to believe that in addition to having anti-diabetic properties, GSE can also be used for diabetes related complications as well.

GSE when administered to STZ induced diabetic rats, modulated pathological changes in apoptosis in neurons and glial studies reveals that it could prevent non enzyme glycation in nerves by extension the prevention of neuropathy. Also, GSE can ameliorate allodynia (diabetic neuropathic pain) [33]. The same groups have worked on the diabetic nephropathy, and have proved that GSE administration results in anti-non enzyme glycosylation in the nephrons of diabetic rats [34]. The oxidative stress induced by diabetes on the nephrons of rat kidney was effectively reduced by GSE, proving it to work for yet another complication of diabetes [35]. Studies have not been carried out in diabetic retinopathy however; GSE is proven to prevent cataract formation in hereditary catractous rats (ICR/f) [35,36]. In an interesting human study conducted in Netherlands, GSE could be effective in reducing $24 \mathrm{~h}$ energy intake in normal to overweight dietary unrestrained subjects, and could, therefore, play a significant role in body-weight management [37].

\section{Conclusion}

Our current civilization is subservient to what we think the modernization of our lifestyle. We are under the constant battle of good vs feel good; most of our diet comes under processed, highly refined and high calorie foods. The impacts of these foods or such lifestyle have an astronomical effect in our system. As much as unhealthy diet prevails in the consumer market, recently health supplements seems to have piqued interest among health care professionals, biomedical researchers, scientists, manufacturers amongst other people. Specific usage, dosage of herbal supplement, its mechanism of action, its involvement and interaction with other drug for the purpose of formulation are some of the many interests that surround health supplements. Grape seed extract has now proven to be the jackpot health supplements as it provides overall health benefits to the consumer. Grape seed both in natural (wine, grape juice) form and as in grape seed extract provides a holistic approach to a disease. As described above, grape seed extract not just helps in a particular symptom of diabetes but rather it provides a complete health care to all the symptoms and the related complications. Grape seed extract exhibits anti-diabetic properties as evidenced by biochemical, molecular studies. Although there are enormous remedial measures to combat the diabetic plague it is imperative to turn our focus to natural drugs with complete understanding of its full potential to reap maximum benefits.

\section{References}

1. WHO (2009) Global health risks: mortality and burden of disease attributable to selected major risks. World Health Organization, Geneva, Swizerland.

2. IDF (2015) IDF diabetes atlas seventh edition. International diabetes federeation, Belegium.

3. Pinhas HO, Zeitler P (2005) The global spread of type 2 diabetes mellitus in children and adolescents. J Pediatr 146(5): 693-700.

4. Kaveeshwar SA, Cornwall J (2014) The current state of diabetes mellitus in India. Australas Med J 7(1): 45-48.

5. Ramachandran A, Snehalatha C (2009) Current scenario of diabetes in India. Journal of diabetes $1(1)$ : 18-28.

6. Farag YM, Gaballa MR (2011) Diabesity: an overview of a rising epidemic. Nephrology Dialysis Transplantation 26(1): 28-35.

7. Ramachandran A, Snehalatha C, Kapur A, Vijay V, Mohan V, et al. (2001) High prevalence of diabetes and impaired glucose tolerance in India: National Urban Diabetes Survey. Diabetologia 44(9): 1094-1101.

8. DeFronzo RA (2004) Pathogenesis of type 2 diabetes mellitus. Medical Clinics of North America,. 88(4): 787-835.

9. Tuomilehto J, Lindström J, Eriksson JG, Valle TT, Hämäläinen H, et al. (2001) Prevention of type 2 diabetes mellitus by changes in lifestyle among subjects with impaired glucose tolerance. N Engl J Med 344(18): $1343-1350$

10. Vilsbøll T, Holst JJ (2004) Incretins, insulin secretion and type 2 diabetes mellitus. Diabetologia 47(3): 357-366.

11. Hu FB, Manson JE, Stampfer MJ, Colditz G, Liu S, et al. (2001) Diet, lifestyle, and the risk of type 2 diabetes mellitus in women. N Engl J Med 345(11): 790-797.

12. Kelley DE, Good paster BH (2001) Effects of exercise on glucose homeostasis in Type 2 diabetes mellitus. Medicine and Science in Sports and Exercise 33(6 Suppl): S495-501.

13. Vermeire E, Wens J, Van Royen P, Biot Y, Hearnshaw H, et al. (2005) Interventions for improving adherence to treatment recommendations in people with type 2 diabetes mellitus. Cochrane Database Syst Rev (2): CD003638.

14. Nathan DM (2002) Initial management of glycemia in type 2 diabetes mellitus. New England Journal of Medicine 347(17): 1342-1349.

15. Ferrières J (2004) The French paradox: lessons for other countries. Heart 90(1): 107-111.

16. Xia EQ, Deng GF, Guo YJ, Li HB (2010) Biological activities of polyphenols from grapes. Int J Mol Sci 11(2): 622-646

17. Packer LM, Hiramatsu M, Yoshikawa T (1999) Antioxidant food supplements in human health. Academic Press p. 511.

18. Shi J, Yu J, Pohorly JE, Kakuda Y (2003) Polyphenolics in grape seedsbiochemistry and functionality. Journal of medicinal food 6(4): 291299.

19. Singleton V, Draper DE (1964) The transfer of polyphenolic compounds from grape seeds into wines. Am J Enol Vitic 15(1): 34-40.

20. Bhandari MR, Jong-Anurakkun N, Hong G, Kawabata J (2008) $\alpha$-Glucosidase and $\alpha$-amylase inhibitory activities of Nepalese medicinal herb Pakhanbhed (Bergenia ciliata, Haw). Food Chemistry 106(1): 247-252. 


\section{Current Research in Diabetes \& Obesity Journal}

21. You Q (2012) Anti-diabetic activities of phenolic compounds in muscadine against alpha-glucosidase and pancreatic lipase. LWT-Food Science and Technology 46(1): 164-168.

22. Adisakwattana S, Jiphimai P, Prutanopajai P, Chanathong B, Sapwarobol $S$, et al. (2010) Evaluation of $\alpha$-glucosidase, $\alpha$-amylase and protein glycation inhibitory activities of edible plants. Int J Food Sci Nutr 61(3): 295-305.

23. Montagut G, Onnockx S, Vaqué M, Bladé C, Blay M, et al. (2010) Oligomers of grape-seed procyanidin extract activate the insulin receptor and key targets of the insulin signaling pathway differently from insulin. J Nutr Biochem 21(6): 476-481.

24. Pinent M, Blay M, Bladé MC, Salvadó MJ, etal. (2004) Grape seed-derived procyanidins have an antihyperglycemic effect in streptozotocininduced diabetic rats and insulinomimetic activity in insulin-sensitive cell lines. Endocrinology 145(11): 4985-4990.

25. Huang D, Ou B, Prior RL (2005) The chemistry behind antioxidant capacity assays. J Agric Food Chem 53(6): 1841-1856.

26. Freedman JE (2008) Oxidative stress and platelets. Arteriosclerosis, thrombosis, and vascular biology 28(3): s11-s16.

27. Chis IC, Ungureanu MI, Marton A, Simedrea R, Muresan A, et al. (2009) Antioxidant effects of a grape seed extract in a rat model of diabetes mellitus. Diab Vasc Dis Res 6(3): 200-204.

28. Clouatre DL, Kandaswami C, Connolly KM (2005) Grape seed extract Encyclopedia of Dietary Supplements. New York, NY: Marcel Dekker p. 309-325.

29. Suwannaphet W, Meeprom A, Yibchok AS, Adisakwattana S (2010) Preventive effect of grape seed extract against high-fructose dietinduced insulin resistance and oxidative stress in rats. Food and Chemical Toxicology 48(7): 1853-1857.
30. Hogan S, Zhang L, Li J, Sun S, Canning C, et al. (2010) Antioxidant rich grape pomace extract suppresses postprandial hyperglycemia in diabetic mice by specifically inhibiting alpha-glucosidase. Nutr Metab (Lond) 7(1): 71.

31. Jariyapamornkoon N, Yibchok S, Adisakwattana S (2013) Inhibition of advanced glycation end products by red grape skin extract and its antioxidant activity. BMC complementary and alternative medicine 13(1): 171.

32. Farrar JL, Hartle DK, Hargrove JL, Greenspan P (2007) Inhibition of protein glycation by skins and seeds of the muscadine grape. Biofactors 30(3): 193-200.

33. Cui XP, Li BY, Gao HQ Wei N, Wang WL (2008) Effects of grape seed proanthocyanidin extracts on peripheral nerves in streptozocininduced diabetic rats. Journal of nutritional science and vitaminology, 54(4): 321-328.

34. Zhou Y (2005) Experiment study on anti-nonenzyme glycosylation effect of grape seed proanthocyanidin extract in diabetic rats. Chin J Geriatr 24: 49-52.

35. Ding Y, Dai X, Jiang Y, Zhang Z, Li Y (2014) Functional and morphological effects of grape seed proanthocyanidins on peripheral neuropathy in rats with type 2 diabetes mellitus. Phytotherapy Research 28(7): 1082-1087.

36. Yamakoshi J, Saito M, Kataoka S, Tokutake S (2002) Procyanidin-rich extract from grape seeds prevents cataract formation in hereditary cataractous (ICR/f) rats. Journal of agricultural and food chemistry 50(17): 4983-4988.

37. Vogels N, Nijs IM, Westerterp PMS (2004) The effect of grape-seed extract on $24 \mathrm{~h}$ energy intake in humans. European journal of clinical nutrition 58(4): 667-673.

\begin{tabular}{l} 
Your next submission with Juniper Publishers \\
will reach you the below assets \\
- Quality Editorial service \\
- Swift Peer Review \\
- Reprints availability \\
- E-prints Service \\
- Manuscript Podcast for convenient understanding \\
- Global attainment for your research \\
- Manuscript accessibility in different formats \\
( Pdf, E-pub, Full Text, Audio) \\
- Unceasing customer service \\
Track the below URL for one-step submission \\
https://juniperpublishers.com/online-submission.php \\
\hline
\end{tabular}

